\title{
Experimental design and response surface methodology applied to the dielectric properties of hydroalcoholic solutions containing sodium chloride
}

Planejamento de experimentos e metodologia de superfície de resposta, aplicados às propriedades dielétricas de soluções hidroalcoólicas com cloreto de sódio

\author{
Anderson dos Santos Morais ${ }^{1 *}$, João Jorge Ribeiro Damasceno', Carlos Henrique Ataíde ${ }^{1}$ \\ ${ }^{1}$ Universidade Federal de Uberlândia (UFU), Faculdade de Engenharia Química, Uberlândia/MG - Brasil
}

\section{*Corresponding Author}

Anderson dos Santos Morais, Universidade Federal de Uberlândia (UFU), Faculdade de Engenharia Química, Bloco 1K, Santa Mônica, CEP: 38408-144, Uberlândia/MG - Brasil, e-mail: ander_morais@yahoo.com.br

Cite as: Experimental design and response surface methodology applied to the dielectric properties of hydroalcoholic solutions containing sodium chloride. Braz. J. Food Technol., v. 21, e2017085, 2018.

\section{Abstract}

The main focus of this study was to use an experimental design to and the response surface statistical technique to predict and optimize the dielectric properties of hydrated ethanol-sodium chloride blends. Several samples of these blends were prepared considering the following variables: hydrated ethyl alcohol concentration, sodium chloride concentration and temperature. The main dielectric properties of these blends, i.e., the dielectric constant, dielectric loss factor and dissipation factor, were measured in a calibrated device suitable for liquid or pasty substances. For this study, experimental tests were carried out according to a Central Composite Design (CCD). Response surface techniques were used to predict the magnitude of the effect of the input variables on the responses investigated, particularly on the dissipation factor. This factor represents the ability of the substance to convert electromagnetic energy into heat. Within the experimental range studied here, the values of the variables that optimized the response were as follows: sodium chloride concentration of $2.21 \%$, hydrated ethanol concentration of $4.64 \%$ and temperature of $87^{\circ} \mathrm{C}$.

Keywords: Ethanol; Dielectric properties; Microwave; Response surface.

\section{Resumo}

O foco principal do trabalho desenvolvido foi utilizar o planejamento de experimentos e as técnicas estatísticas de superfície de resposta para predizer e otimizar as propriedades dielétricas de misturas etanol hidratado-cloreto de sódio. Várias amostras dessas misturas foram preparadas, considerando-se as seguintes variáveis: concentração de álcool etílico hidratado, concentração de cloreto de sódio e temperatura. As principais propriedades dielétricas, como constante dielétrica, fator de perda dielétrica e fator de dissipação das misturas, foram medidas num equipamento calibrado, indicado para substâncias líquidas ou pastosas. Para este estudo, ensaios experimentais foram conduzidos, seguindo um Planejamento Composto Central (PPC). Técnicas de superfície de resposta foram utilizadas para predizer a magnitude do efeito das variáveis de entrada nas respostas investigadas, particularmente no fator de dissipação. Tal fator representa a habilidade da substância em converter energia eletromagnética em calor. Considerando-se a faixa experimental estudada, os valores das variáveis que otimizaram a resposta foram os seguintes: concentração de cloreto de sódio de $2,21 \%$, concentração de etanol hidratado de $4,64 \%$ e temperatura de $87^{\circ} \mathrm{C}$.

Palavras-chave: Etanol; Propriedades dielétricas; Microondas; Superfície de resposta. 


\section{Introduction}

The productive capacity and sustainable development of the Brazilian sugar and ethanol industry have aroused strong interest worldwide, since this is the first economy that has achieved the sustainable use of biofuels.

These days, sugarcane alcohol is recognized worldwide for its environmental and socioeconomic advantages, and first world countries are interested in this technology. In Brazil, the sugarcane supply chain employs more than four million people in direct and indirect jobs, generating more than $\mathrm{R} \$ 41$ billion per year in the sector (BICALHO et al., 2012).

Brito (2003) stated that the Brazilian sugarcane sector may become the main global fuel alcohol supplier as well as using modern technologies to set up distilleries in other countries. Thus the growing demand for ethanol and the increasing competitiveness of the current world market are driving researchers and companies operating in the sector to seek high productivity processes allied to lower operating costs, e.g., energy consumption during the heating of the fermented sugarcane juice in the distillation operation. Experts have warned that efficiency gains in commodity production are predominant factors for competitiveness on world markets (BICALHO et al., 2012).

In the conventional processes used by most Brazilian distilleries, sugarcane juice is heated in tubular heat exchangers (reboilers), using water vapour to provide the energy needed for partial vaporization.

Microwave heating has made advances in recent years and the number of relevant industrial applications has increased, particularly in the food sector. Interest in this type of heating has increased, to a great extent due to the energy crisis, but also due to greater familiarization with and wider acceptance of this technology (ZHANG et al., 2006).

Knowledge about dielectric properties such as the dielectric constant ( $\left.\varepsilon^{\prime}\right)$ and the dielectric loss factor ( $\left.\varepsilon^{\prime \prime}\right)$, a well as their relationships in liquid substances, is essential in order to determine the amount of electromagnetic energy needed for the dielectric heating of compounds (PROSETYA; DATTA, 1991).

Dielectric materials have low conduction current when a given external electric field is applied. Thus, the molecules and atoms of these materials present a dipole movement that creates friction, dissipating energy in the form of heat (PEYRE et al., 1997). Dielectric properties, which vary with the frequency applied, play an important role in the efficient heating of these substances. However, it is difficult to predict heat transfer in microwave heating, due to the nonlinear variations in the properties of materials as a function of temperature and composition, as was noted by Campañone and Zaritzky (2005) and Koskiniemi et al. (2011).
These variations may cause thermal instabilities, which are known as hot spots (AHMED et al., 2007).

Earlier studies, for instance that of Chen and Zhao (2007), reported values for the ( $\left.\varepsilon^{\prime}\right)$ and ( $\left.\varepsilon^{\prime \prime}\right)$ of pure ethanol and water. However, these properties need to be determined for blend of these substances, since this information is important for their microwave heating.

Gadani et al. (2012) attributed significant improvements in the dielectric properties of water to the addition of salts. Their results indicated that the highest conversion of electromagnetic energy into heat was achieved by increasing the concentration of sodium chloride in aqueous solutions.

Electromagnetic energy is transformed into heat by microwaves via two main mechanisms: dipole rotation and ionic conduction. The first mechanism involves the alignment of the molecules with the electric field applied. In the second mechanism, the heat produced is due to friction losses that occur due to the migration of dissolved ions under the action of an electromagnetic field (electromigration) (KOSKINIEMI et al., 2013).

Microwave heating is one of the most interesting methods for heating materials with favourable dielectric characteristics. Unlike other heat sources, which involve the application of heat externally to the surface of a material, microwave irradiation heats the entire volume of the material (GEEDIPALLI et al., 2007).

This type of heating offers several advantages over conventional methods, such as minimization of the heating time and a uniform distribution of temperature in the material (OLIVEIRA; FRANCA, 2002).

Sun et al. (2007) reported that these characteristics can provide improvements in the quality of products in various industrial fields, e.g., sterilization of materials, sewage treatment, pyrolysis (carbonization), drying, pasteurization, etc.

Authors such as Metaxas and Meredith (1993), Meredith (1998), Yin (2012), Maskan (2000) and Drouzas and Schubert (1996) carried out experimental studies involving microwave technology to process a variety of materials, such as juice pasteurization, drying processes, sample preparation, etc.

The U.S. Federal Communications Commission (FCC) defined the frequencies of $0.915 \mathrm{GHz}$ and $2.45 \mathrm{GHz}$ for the purpose of industrial microwave heating. However, the frequency bandwidth of from 0.9 to $18 \mathrm{GHz}$ is already used by some microwave heating systems (BOOTY; KRIEGSMANN, 1994).

This work involved a study of the variation in the dielectric properties of hydrated ethanol-sodium chloride blends at a frequency of $2.45 \mathrm{GHz}$, aiming to select the best microwave heating conditions for these blends. To this 
end, the Design of Experiments (DOE) and Response Surface Methodology were used.

The independent variables analysed were: the salt $(\mathrm{NaCl})$ concentration $-\mathrm{C}_{\mathrm{NaCl}}$, the ethanol

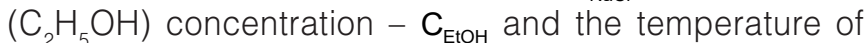
the blend $-\mathrm{T}$, while the dependent variables were: the dielectric constant $\left(\varepsilon^{\prime}\right)$, the dielectric loss facto $\left(\varepsilon^{\prime \prime}\right)$ and the dissipation factor $\left(\operatorname{tg} \delta=\varepsilon^{\prime \prime} / \varepsilon^{\prime}\right)$.

\section{Dielectric properties}

Let us consider two parallel metal plates placed at a fixed distance from each other in a vacuum. There will be a capacitance between them but if one fills the vacuum with some sort of material, the capacitance will change to a new value.

The relationship between the two aforementioned capacitances is called the permittivity of the material ( $k)$, and is given by the Debye equation (Equation 1):

$\mathrm{k}=\frac{\varepsilon}{\varepsilon_{\mathrm{o}}}=\varepsilon^{\prime}-\mathrm{i} \varepsilon^{\prime \prime}$

where: $\varepsilon$ ' is the real part, $\varepsilon$ " is the imaginary part, and $\varepsilon_{0}=\frac{1}{36 \pi} \times 10^{-9} \mathrm{~F} / \mathrm{m}$ to $\mathrm{i}=\sqrt{-1}$.

The separation of the real and imaginary parts in Debye's equation allows one to establish the following expressions for the dielectric constants: $\varepsilon$ 'and $\varepsilon$ "Equations 2 and 3. These constants are dependent on the frequency of radiation $(\varpi)$ and the viscosity of the continuous medium and temperature during the relaxation time $(\tau)$.

$\varepsilon^{\prime}=\varepsilon_{\infty}+\frac{\left(\varepsilon_{\mathrm{s}}-\varepsilon_{\infty}\right)}{\left(1+\omega^{2} \tau^{2}\right)}$

$\varepsilon^{\prime \prime}=\frac{\left(\varepsilon_{\mathrm{s}}-\varepsilon_{\infty}\right) \omega \tau}{\left(1+\omega^{2} \tau^{2}\right)}$

where: $\varepsilon_{\infty}$ and $\varepsilon_{\mathrm{s}}$ are, respectively, the permittivities of the material at very high $\left(>>\tau^{-1}\right)$ and extremely low $\left(<<\tau^{-1}\right)$ radiation frequencies, and $\tau$ is the relaxation time obtained by Debye, based on the Stokes-Einstein theorem (METAXAS; MEREDITH, 1993).

The dielectric loss factor ( $\left.\varepsilon^{\prime \prime}\right)$ measures the efficiency of the conversion of electromagnetic energy into heat.

The dielectric constant $\left(\varepsilon^{\prime}\right)$ of a substance is a measure of its degree of polarity. The higher the dielectric constant of a material the more energy can be stored in it (ZHU et al., 2007).

The $\varepsilon^{\prime \prime} / \varepsilon^{\prime}$ ratio, which is numerically equal to $\tan \delta$ and is called the dissipation factor, indicates the ability of a sample to convert electromagnetic radiation into heat. According to Kingston and Haswell (1997), the higher the value of this factor the greater the ability of a substance to be heated by microwaves.
The dielectric constant $\left(\varepsilon^{\prime}\right)$ is associated with the capacity of the material to store electric energy (in a vacuum $\varepsilon^{\prime}=1$ ), while the dielectric loss factor $\left(\varepsilon^{\prime \prime}\right)$ is related to the dissipation of electric energy due to different mechanisms. The dielectric properties describe the ability of a material to absorb, transmit and reflect electromagnetic energy. Foods are neither good electrical insulators nor good electrical conductors; and can therefore be categorized as 'lousy dielectric materials'. The dielectric properties of foods have the ability to drive the influential interaction between the food components and the electric field, and can be influenced by many factors such as temperature, moisture content, salt content, microwave frequency and other ingredients. The microwave heating mechanism is very complex and depends on numerous factors i.e. the propagation of microwaves governed by Maxwell's equations for electromagnetic waves, the interactions between the microwaves and the dielectric properties of the food, and the heat dissipation governed by heat and mass transfer (PULIGUNDLA et al., 2013)

According to Cha-Um et al. (2009), any material that can store energy when an external electric field is applied to it is a dielectric material.

Such materials resist the passage of electric current, but have the ability to absorb and store electric energy due to charge displacement (polarization) under the influence of an electric field.

The dielectric properties of materials are often temperature-dependent. Therefore, these properties should be known in a wide range of temperatures to allow for more accurate predictions of the dielectric heating behaviour.

Knowledge of the dielectric properties of materials is required in studies of the microwave heating of these materials, enabling one to select the best operational conditions, and hence, the best use of energy.

\section{Material and methods}

\subsection{Dielectric properties}

First the hydrated ethanol and sodium chloride solutions were prepared at concentrations of $\mathrm{C}_{\mathrm{NaCl}}$ $(0.19,0.6,1.2,1.8$ and $2.21 \% \mathrm{w} / \mathrm{w})$ and $\mathrm{C}_{\mathrm{EtOH}}$ $(4.64,6,8,10$ and $11.36 \% \mathrm{w} / \mathrm{w})$, as defined by the experimental design Table 1.

With the aid of an analytical balance, the samples were prepared using $99.9 \%$ ethanol $\left(\mathrm{Merck}^{\circledR}\right), \mathrm{NaCl}$. p.a. $\left(\right.$ Synth $\left.^{\circledR}\right)$ and deionized water, and the mixtures stored in

Table 1. The design variables and levels.

\begin{tabular}{crrrrr} 
Coded variables & \multicolumn{1}{c}{$(-\alpha)$} & \multicolumn{1}{c}{$\mathbf{1}$} & \multicolumn{1}{c}{$\mathbf{0}$} & \multicolumn{1}{c}{$\mathbf{1}$} & \multicolumn{1}{c}{$(\alpha)$} \\
$\mathrm{C}_{\mathrm{NaCl}}$ & 0.19 & 0.60 & 1.20 & 1.80 & 2.21 \\
$\mathrm{C}_{\mathrm{EtOH}}$ & 4.64 & 6.00 & 8.00 & 10.00 & 11.36 \\
$\mathbf{T}$ & 53.00 & 60.00 & 70.00 & 80.00 & 87.00 \\
\hline
\end{tabular}


Experimental design and response surface methodology applied to the dielectric properties of hydroalcoholic solutions containing sodium chloride

Morais, A. S. et al.

$150 \mathrm{~mL}$ containers. The concentrations were selected to match the operating conditions of industrial ethanol distillation.

The dielectric propeties of the different hydrated ethanol and sodium chloride blends were determined in a frequency range from $10 \mathrm{MHz}$ to $3.0 \mathrm{GHz}$, at temperatures of $53^{\circ} \mathrm{C}, 60^{\circ} \mathrm{C}, 70{ }^{\circ} \mathrm{C}, 80^{\circ} \mathrm{C}$ and $87^{\circ} \mathrm{C}$ Table 1 , duly controlled in a thermostatic bath, as illustrated in Figure 1.

The materials used for determining the dielectric properties were: a Coaxial Probe, Transmission Line, Resonant Cavity and Parallel Plates. The coaxial probe method was chosen because it is non-destructive and is recommended for liquid or pasty samples. This method is used to determine the real and imaginary parts of permittivity $(\mathrm{k})$ and the loss tangent $(\tan \delta)$.

\subsection{Coaxial probe method}

The coaxial probe method consists of determining the dielectric properties of a mixture using a network analyser set up for this purpose, specific software and the probe, as illustrated in Figure 2.

The probe shown in Figure 3 has a hermetic glass-to-metal seal which makes it resistant to corrosion and abrasive chemicals. It can withstand temperatures ranging from $-40{ }^{\circ} \mathrm{C}$ to $200^{\circ} \mathrm{C}$ and allows measurements to be taken as a function of frequency and of temperature.

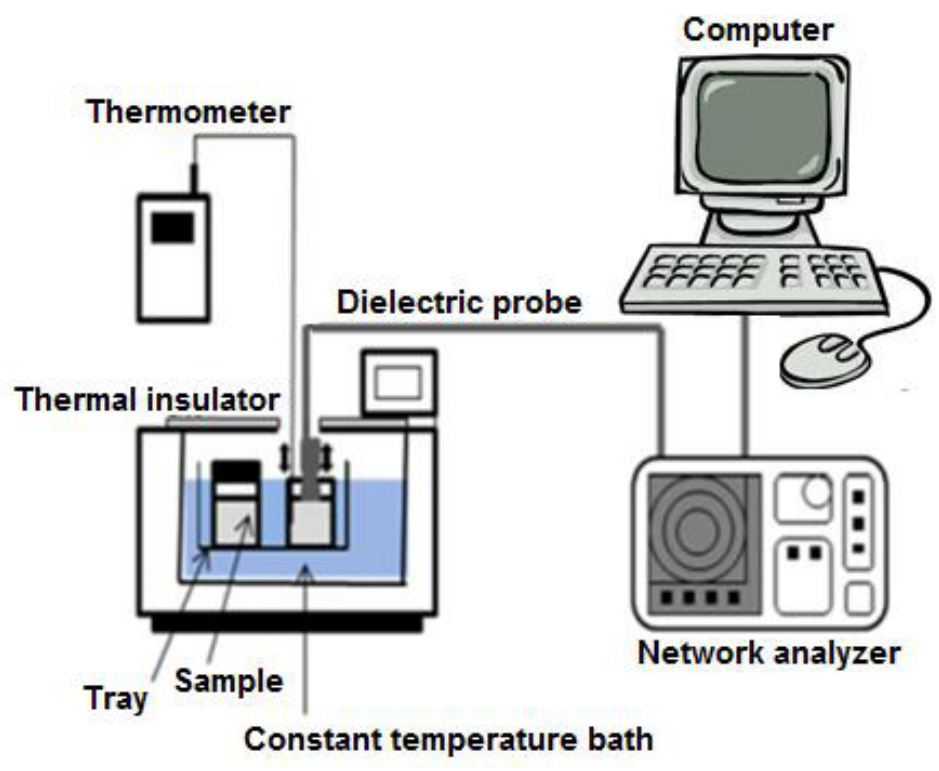

Figure 1. Schematic diagram of the system for determining the dielectric properties. Adapted from Tanaka et al. (2008).

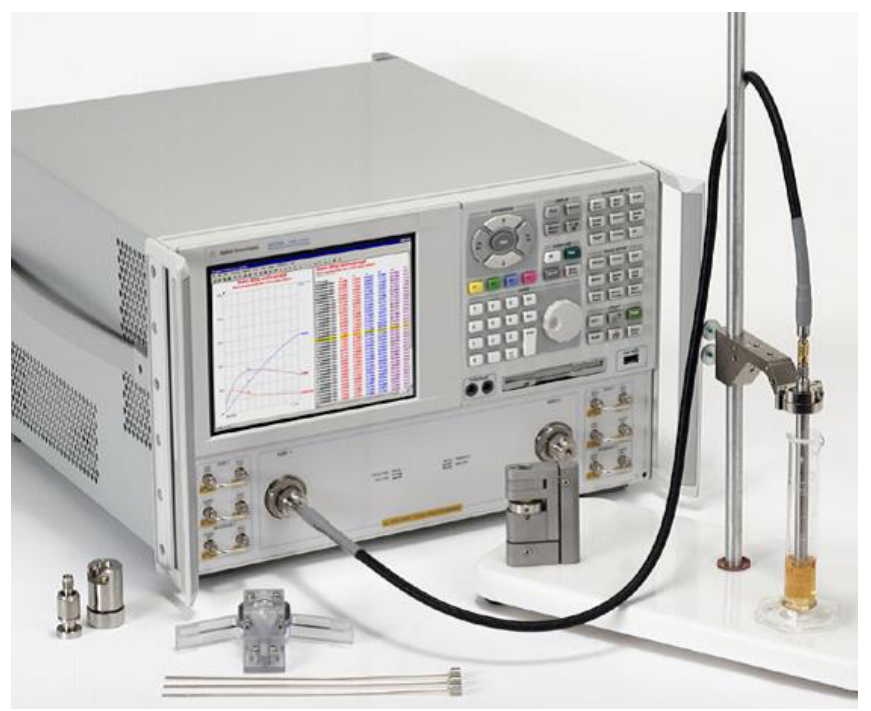

Figure 2. Measuring system setup.

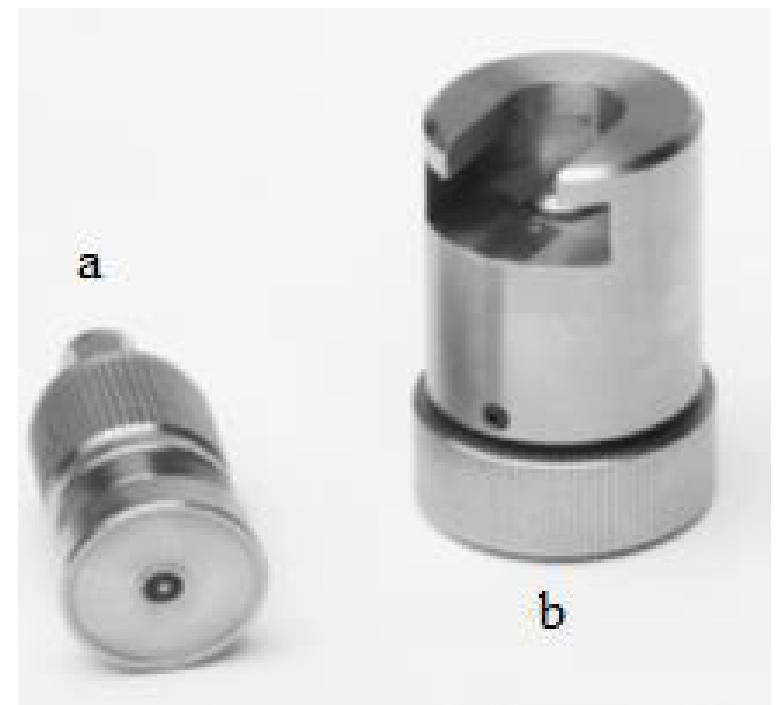

Figure 3. (a) Probe and (b) calibrator. 
Experimental design and response surface methodology applied to the dielectric properties of hydroalcoholic solutions containing sodium chloride

Morais, A. S. et al.

The devices used were an Agilent 85070D dielectric probe kit, Agilent E5071C ENA network analyser and Agilent 85070E software.

Before taking the measurements the system was calibrated. This involved selecting the desired frequency range, using a sample of water at approximately $25^{\circ} \mathrm{C}$, and calibrating the system in a pre-selected sequence: testing in air; testing in short circuit, and testing in water.

After the calibration was completed, the dielectric constant of the water and alcohol, both of which were known, were tested for safety. Having confirmed these values it was then possible to measure the dielectric constant of the prepared blends.

\subsection{Experimental design and response surface}

To select the best operating values to obtain the dielectric properties using the microwave heating system and the cited variables, a Central Composite Design (CCD) was prepared, comprising a factorial design at five levels with three variables, three replicates at the centre point and six experiments at the axial points $(\alpha)$, giving a total of 17 experiments Table 2.

Each assay lasted for about 1 min after the temperature reached equilibrium, and $\varepsilon^{\prime \prime}, \varepsilon^{\prime}$ and $\operatorname{tg} \delta$ were represented by the responses " $y, y$ and $y$ ", respectively. Optimization was only done at the frequency of $2.45 \mathrm{GHz}$, which is the one most widely used industrially.

A volume of $50 \mathrm{~cm}^{3}$ of solution was used in each assay.

The variables were coded according to Equations 4, 5 and 6 . The following variables were selected:

Table 2. The design matrix, showing the operating conditions of the 17 experiments.

\begin{tabular}{cccc} 
Experiment & $\boldsymbol{x}_{\mathbf{1}}(\boldsymbol{\%})$ & $\boldsymbol{x}_{\mathbf{2}}(\boldsymbol{\%})$ & $\left.\boldsymbol{x}_{\boldsymbol{3}}{ }^{\circ} \mathbf{C}\right)$ \\
\hline 1 & 0.60 & 6.00 & 60 \\
2 & 1.80 & 6.00 & 60 \\
3 & 0.60 & 10.00 & 60 \\
4 & 1.80 & 10.00 & 60 \\
5 & 0.60 & 6.00 & 80 \\
6 & 1.80 & 6.00 & 80 \\
7 & 0.60 & 10.00 & 80 \\
8 & 1.80 & 10.00 & 80 \\
9 & 0.19 & 8.00 & 70 \\
10 & 2.21 & 8.00 & 70 \\
11 & 1.20 & 4.64 & 70 \\
12 & 1.20 & 11.36 & 70 \\
13 & 1.20 & 8.00 & 53 \\
14 & 1.20 & 8.00 & 87 \\
15 & 1.20 & 8.00 & 70 \\
16 & 1.20 & 8.00 & 70 \\
17 & 1.20 & 8.00 & 70 \\
\hline
\end{tabular}

$x$, sodium chloride concentration (\%) $-\mathrm{C}_{\mathrm{Nacl}} ; x_{2}$, ethanol concentration (\%) $-\mathrm{C}_{\text {EtoH }}$, and $x_{3}$, temperature $\left({ }^{\circ} \mathrm{C}\right)-\mathrm{T}$.

$\mathrm{x}_{1}=\frac{\mathrm{C}_{\mathrm{NaCl}}-1.2}{0.6}$

$\mathrm{x}_{2}=\frac{\mathrm{C}_{\mathrm{EtOH}}-8}{2}$

$x_{3}=\frac{T-70}{10}$

Response Surface Methodology (RSM) comprises a combination of techniques for experimental designs, regression analysis and optimization methods and is very useful for product and process development, and also to improve existing products.

The model is built by means of a multiple regression analysis, which involves estimating the regression coefficients of the variables. The adoption of a complete quadratic regression model is recommended, as suggested by Equation 7.

$$
Y=\beta_{0}+\sum_{i}^{n} \beta_{i} X_{i}+\sum_{i}^{n} \beta_{i i} X_{i}^{2}+\sum_{i=1}^{n} \sum_{j=1}^{n} \beta_{i j} X_{i} X_{j}
$$

where: $\beta_{0}, \beta_{\mathrm{i}}, \beta_{\mathrm{ii}}$ and $\beta_{\mathrm{ji}}=\beta_{\mathrm{ij}}$ represent the coefficients of the polynomial and $x_{i}, x_{j}$ are the experimental variables.

After building the model, the fit of the regression must be checked and a procedure that is commonly used for this is the Student's $t$-test and the analysis of variance, as described by Körbahti and Rauf (2008).

After adjusting the model, the next step is to optimize it.

In the case of a second-degree model, quadratic programming can be applied, as proposed by Ravikumar et al. (2005).

El Boulifi et al. (2010) and Montgomery (2001) stated that one way to locate the optimal point is to use the stationary point localization technique and the Central Composite Design (described above). The optimal point, if it really exists in the system under investigation, will be defined by the set of points $\left(x_{1}, x_{2}, \ldots, x_{k}\right)$ for which the partial derivatives are equal to zero, according to Equation 8.

$$
\frac{\partial \mathrm{y}}{\partial \mathrm{x}_{1}}=\frac{\partial \mathrm{y}}{\partial \mathrm{x}_{2}}=\ldots=\frac{\partial \mathrm{y}}{\partial \mathrm{x}_{\mathrm{k}}}
$$

This point, which is called the stationary point, may represent a maximum response point, a minimum point or a saddle point.

The general solution for the stationary point is obtained when the second-order calculation of Equation 7 is written in matrix notation, as shown in Equation 9,

$y=\beta_{0}+x^{\prime} b+x^{\prime} B x$ 
Experimental design and response surface methodology applied to the dielectric properties of hydroalcoholic solutions containing sodium chloride

Morais, A. S. et al.

where:

$\mathrm{x}=\left[\begin{array}{c}\mathrm{x}_{1} \\ \mathrm{x}_{2} \\ \cdot \\ \cdot \\ \cdot \\ \mathrm{x}_{\mathrm{k}}\end{array}\right] \quad \mathrm{b}=\left[\begin{array}{c}\beta_{1} \\ \beta_{2} \\ \cdot \\ \cdot \\ \cdot \\ \beta_{\mathrm{k}}\end{array}\right] \quad \mathrm{B}=\left[\begin{array}{rrrr}\beta_{11} & \beta_{12} / 2 & \cdots & \beta_{11} / 2 \\ & \beta_{22} & \cdots & \beta_{21} / 2 \\ & & \cdots & \cdot \\ & & & \cdot \\ & & & \beta_{\mathrm{kk}}\end{array}\right]$

Thus it is possible to estimate the optimal levels of each of the input parameters that maximize or minimize the average response of the system.

\section{Results and discussion}

The influence of the variables: $x$ sodium chloride concentration (\%) $-\mathrm{C}_{\mathrm{NaCl}} ; x_{2}$, ethanol concentration $(\%)-\mathrm{C}_{\mathrm{EtOH}}$, and $x_{3}$, temperature $\left({ }^{\circ} \mathrm{C}\right)-\mathrm{T}$ on the dielectric properties $\varepsilon$ ", $\varepsilon^{\prime}$ and $\operatorname{tg} \delta$ were studied according to a central composite design with three replicates at the centre, giving a total of 17 experiments.
The experimental results are shown in Table 3. Based on these results, the parameters of the regression models were estimated by applying Equation 7 .

The experimental data were subjected to a multiple regression analysis to quantify the effect of the main variables as well as the effects of the interaction and quadratic contributions to the responses under study. A maximum probability of error of $10 \%$ was established in the test and hence the parameters with a significance level higher than $10 \%$ were ignored. The statistical analysis and mathematical processing were carried out with the aid of the STATISTICA 8 and MAPLE 9.5 software, respectively.

The accuracy of the experimental results was verified based on an evaluation of the results obtained at the central design level, where the differences between the responses were less than $0.5 \%$.

Tables 4, 5 and 6 show the results obtained from applying multiple regressions to the responses obtained for $\varepsilon^{\prime}, \varepsilon^{\prime \prime}$ and $\operatorname{tg} \delta$. A comparison of the $p$ levels observed and the $p$ level stipulated by the significance of $10 \%$ indicates

Table 3. Experimental results.

\begin{tabular}{|c|c|c|c|c|c|}
\hline$x_{1}$ & $x_{2}$ & $x_{3}$ & $y 1 \varepsilon "$ & $y 2 \varepsilon^{\prime}$ & $y 3 \operatorname{tg} \delta$ \\
\hline-1 & -1 & -1 & 65.7843 & 25.7205 & 2.5577 \\
\hline 1 & -1 & -1 & 62.7598 & 16.5267 & 3.7975 \\
\hline-1 & 1 & -1 & 63.043 & 21.9390 & 2.8736 \\
\hline 1 & 1 & -1 & 61.1245 & 18.0666 & 3.3833 \\
\hline-1 & -1 & 1 & 64.2749 & 27.7580 & 2.3155 \\
\hline 1 & -1 & 1 & 60.2523 & 15.0664 & 3.9991 \\
\hline-1 & 1 & 1 & 59.9301 & 22.3730 & 2.6787 \\
\hline 1 & 1 & 1 & 58.5546 & 14.1140 & 4.1487 \\
\hline-1.682 & 0 & 0 & 63.084 & 27.6120 & 2.2847 \\
\hline 1.682 & 0 & 0 & 59.8527 & 18.3052 & 3.2697 \\
\hline 0 & -1.682 & 0 & 65.0083 & 29.1054 & 2.2336 \\
\hline 0 & 1.682 & 0 & 60.2302 & 26.0313 & 2.3137 \\
\hline 0 & 0 & -1.682 & 63.6284 & 21.4045 & 2.9727 \\
\hline 0 & 0 & 1.682 & 59.4921 & 14.9332 & 3.9839 \\
\hline 0 & 0 & 0 & 61.299 & 25.6367 & 2.3911 \\
\hline 0 & 0 & 0 & 61.301 & 25.6363 & 2.3912 \\
\hline 0 & 0 & 0 & 61.298 & 25.6359 & 2.3911 \\
\hline
\end{tabular}

Table 4. Multiple regression analysis for y1 ( $\left.\varepsilon^{\prime \prime}\right)$.

\begin{tabular}{ccccc}
\hline & Coefficients & & Error & t (10) \\
$\beta_{0}$ & 61.4671 & 0.0977 & 629.00 & $2.54 \mathrm{E}-24$ \\
$\beta_{1}$ & -1.1551 & 0.0803 & -14.38 & $5.25 \mathrm{E}-08$ \\
$\beta_{2}$ & -1.3513 & 0.0803 & -16.82 & $1.16 \mathrm{E}-08$ \\
$\beta_{3}$ & -1.2196 & 0.0803 & -15.18 & $3.11 \mathrm{E}-08$ \\
$\beta_{22}$ & 0.4376 & 0.0822 & 5.32 & $3.37 \mathrm{E}-04$ \\
$\beta_{12}$ & 0.4691 & 0.1050 & 4.47 & $1.20 \mathrm{E}-03$ \\
$\beta_{23}$ & -0.2082 & 0.1050 & -1.98 & $7.54 \mathrm{E}-02$ \\
\hline
\end{tabular}


Experimental design and response surface methodology applied to the dielectric properties of hydroalcoholic solutions containing sodium chloride

Morais, A. S. et al.

Table 5. Multiple regression analysis for y2 ( $\left.\varepsilon^{\prime}\right)$.

\begin{tabular}{|c|c|c|c|c|}
\hline \multicolumn{2}{|c|}{ Coefficients } & Error & $t(13)$ & $\boldsymbol{P}$ \\
\hline$\beta_{0}$ & 25.9524 & 1.1114 & 23.35 & 5.34E-12 \\
\hline$\beta_{1}$ & -3.6367 & 0.6952 & -5.23 & 1.62E-04 \\
\hline$\beta_{11}$ & -1.5450 & 0.7309 & -2.11 & 5.44E-02 \\
\hline$\beta_{33}$ & -3.2380 & 0.7309 & -4.43 & $6.79 \mathrm{E}-04$ \\
\hline \multicolumn{5}{|c|}{ Level of significance $(\alpha) 0.10$} \\
\hline
\end{tabular}

Table 6. Multiple regression analysis for y3 $(\operatorname{tg} \delta)$.

\begin{tabular}{ccccc} 
& Coefficients & & Error (13) & P \\
$\beta_{0}$ & 2.4146 & 0.1588 & 15.21 & $1.16 \mathrm{E}-09$ \\
$\beta_{1}$ & 0.4803 & 0.0993 & 4.84 & $3.25 \mathrm{E}-04$ \\
$\beta_{11}$ & 0.2033 & 0.1044 & 1.95 & $7.35 \mathrm{E}-02$ \\
$\beta_{33}$ & 0.4511 & 0.1044 & 4.32 & $8.31 \mathrm{E}-04$ \\
\hline
\end{tabular}

that, for the response $y(\varepsilon ")$ only $\mathbf{x}_{1}, \mathbf{x}_{2}, \mathbf{x}_{3}, \mathbf{x}_{2}^{2}$ and $\mathbf{x}_{1} \cdot \mathbf{x}_{2}$ were significant. For the response $y\left(\varepsilon^{\prime}\right)$ only $x_{1}, x_{1}^{2}$ and $x_{3}^{2}$ were significant, and for the response $y(\operatorname{tg} \delta)$ only $x_{1}, x_{1}^{2}$ and $\mathrm{x}_{3}^{2}$ were significant.

Thus one can establish equations or models for the $\varepsilon$ ', $\varepsilon "$ and $\operatorname{tg} \delta$ responses which are represented, respectively, by Equations 10,11 and 12 for the response surface analysis. It should be noted that these equations contain only the variables and interactions that significantly influenced the response.

$$
\varepsilon^{\prime \prime}=61.4671-1.155 \cdot x_{1}-1.3513 \cdot x_{2}-1.2196 \cdot x_{3}+
$$$$
0.4376 \cdot x_{2}^{2}+0.4691 \cdot x_{1} \cdot x_{2}-0.2082 \cdot x_{2} \cdot x_{3}
$$

$$
\begin{aligned}
& \varepsilon^{\prime}=25.9524-3.6367 \cdot x_{1}-1.5450 \cdot x_{1}^{2}-3.2380 \cdot x_{3}^{2} \\
& \operatorname{tg} \delta=2.4146+0.4803 \cdot x_{1}+0.2033 \cdot x_{1}^{2}+0.4511 \cdot x_{3}^{2}
\end{aligned}
$$

An analysis of the residuals indicated that they followed a normal distribution and were distributed independently with constant variance, as can be seen from the random dispersions in Figures 4, 5 and 6.

The relationships between the predicted and observed dependent variables are shown in Figures 7, 8 and 9. The observed values were measured experimentally and the predicted values were evaluated from the equations generated using function approximation, Equations 10, 11 and 12.

According to the fitted models, the values obtained for the correlation coefficients for the responses of $\varepsilon^{\prime \prime}, \varepsilon^{\prime}$ and $\operatorname{tg} \delta$ were $0.9872,0.7878$ and 0.7680 , respectively.

The effects of two independent variables and their interactions in the responses can be seen by analysing the response surfaces in Figures 10 to 18, which were built from Equations 10, 11 and 12, considering the third variable at its central point.

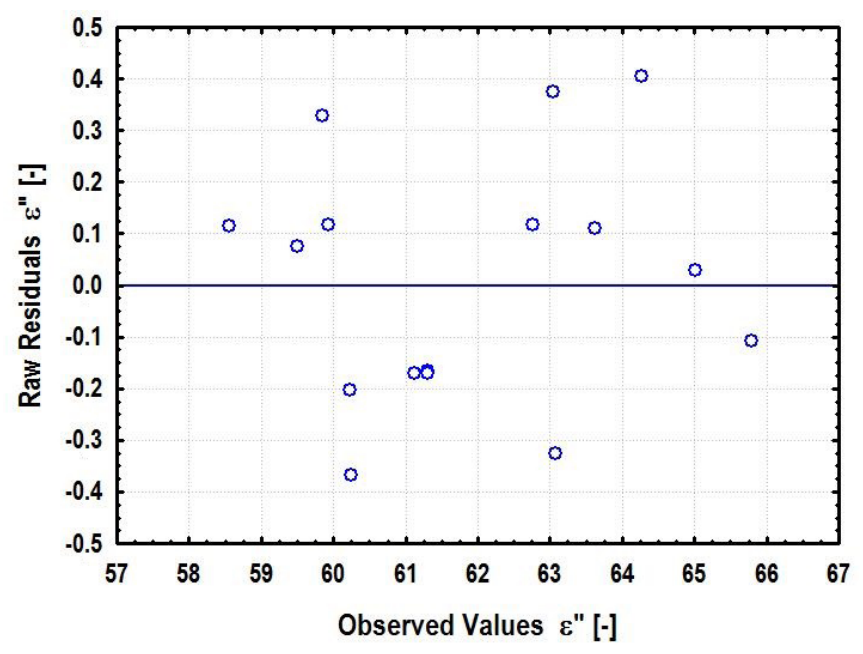

Figure 4. Graph of residuals for $y_{1}(\varepsilon ")$.

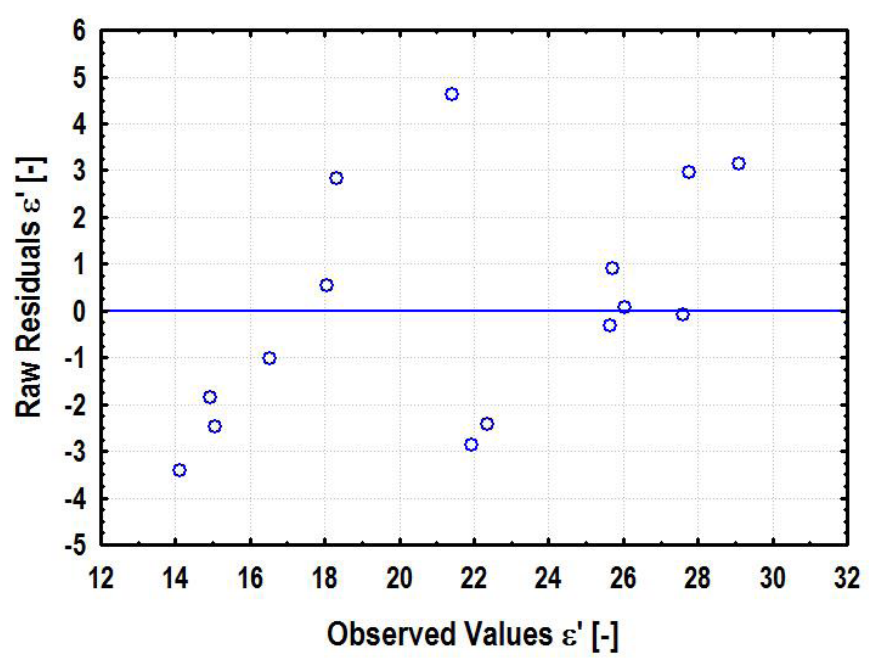

Figure 5. Graph of residuals for $\mathrm{y}_{2}\left(\varepsilon^{\prime}\right)$. 
Experimental design and response surface methodology applied to the dielectric properties of hydroalcoholic solutions containing sodium chloride

Morais, A. S. et al.

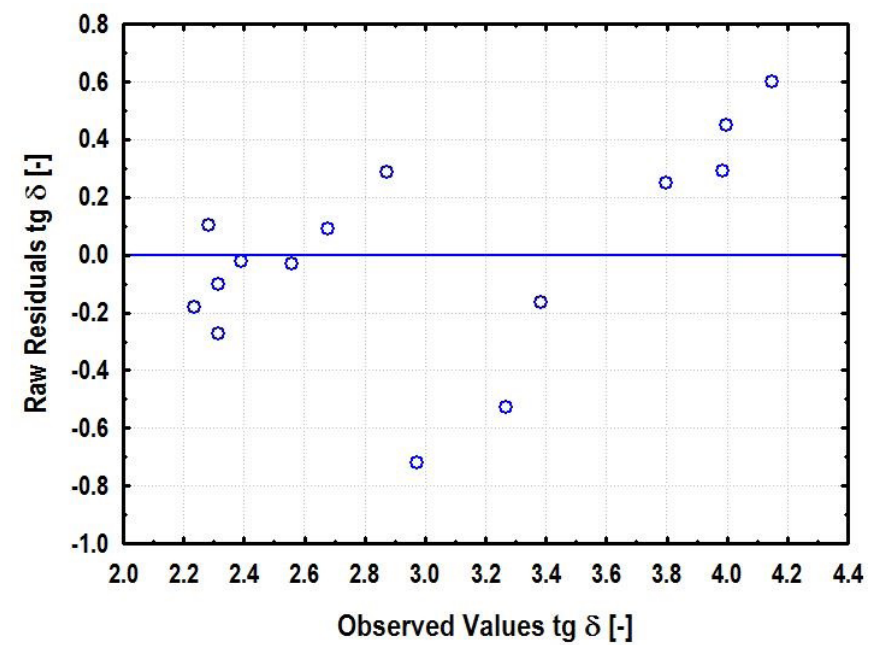

Figure 6. Graph of residuals for $y_{3}(\operatorname{tg} \delta)$.

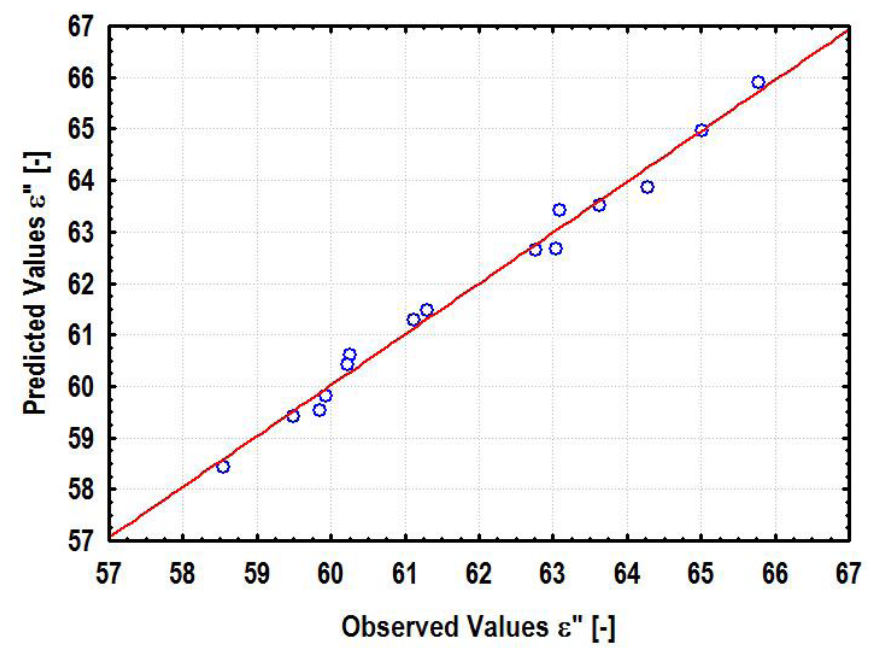

Figure 7. Estimated vs. observed values for $\mathrm{y}_{1}\left(\varepsilon^{\prime \prime}\right)$.

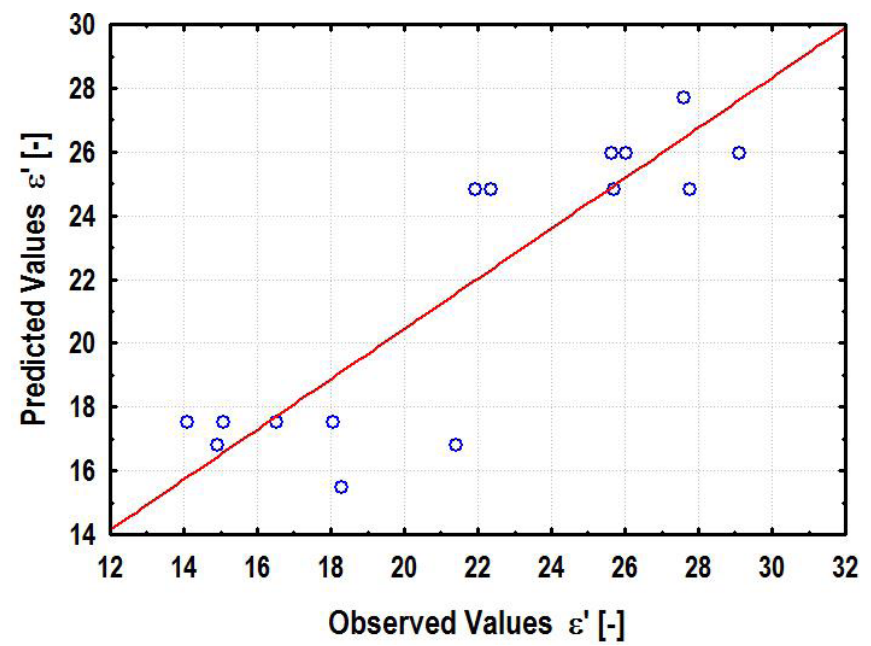

Figure 8. Estimated vs. observed values for $y_{2}\left(\varepsilon^{\prime}\right)$.

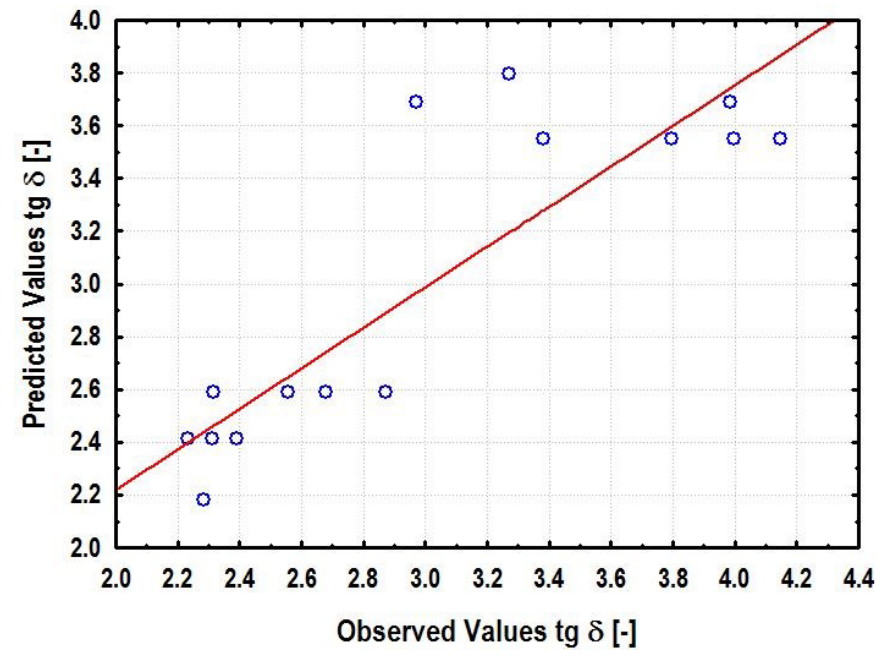

Figure 9. Estimated vs. observed values for $\mathrm{y}_{3}(\operatorname{tg} \delta)$.

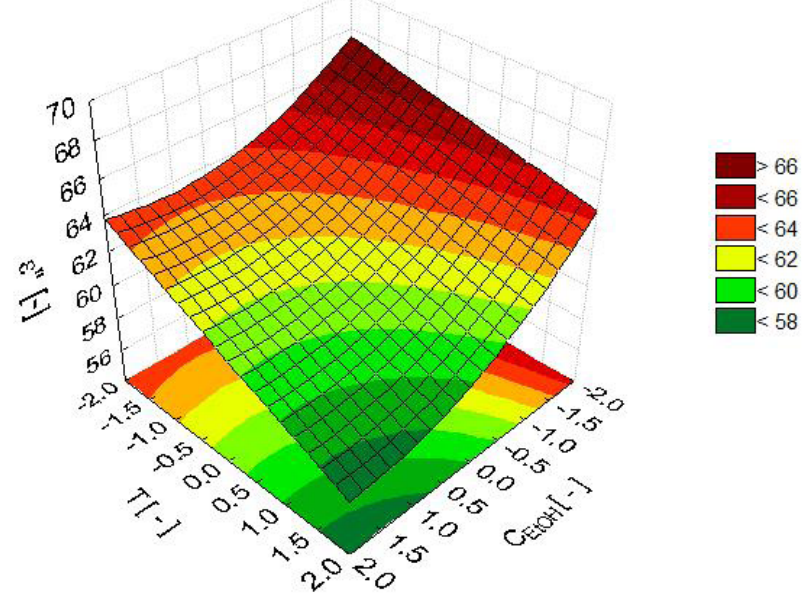

Figure 10. Response surface for $\mathrm{y}_{1}-\varepsilon^{\prime \prime}[-]$ with fixed $\mathrm{C}_{\mathrm{NaCl}} \times[-]$.

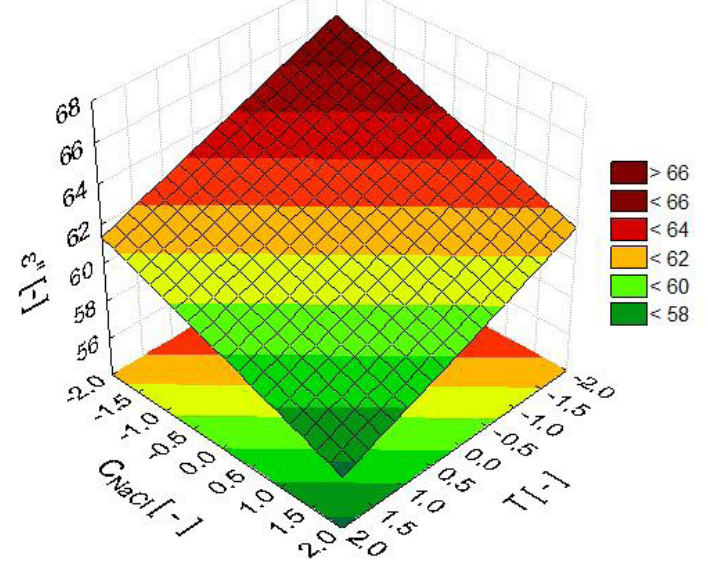

Figure 11. Response surface for $\mathrm{y}_{1}\left(\varepsilon^{\prime \prime}\right)$ with fixed $\mathrm{C}_{\mathrm{EtOH}} \times[-]$. 
Experimental design and response surface methodology applied to the dielectric properties of hydroalcoholic solutions containing sodium chloride

Morais, A. S. et al.

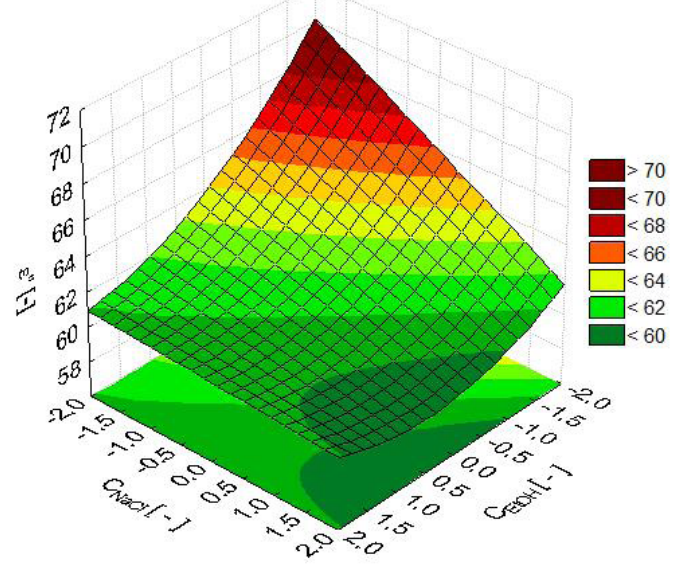

Figure 12. Response surface for $y_{1}-\varepsilon^{\prime \prime}[-]$ with fixed $x T[-]$.

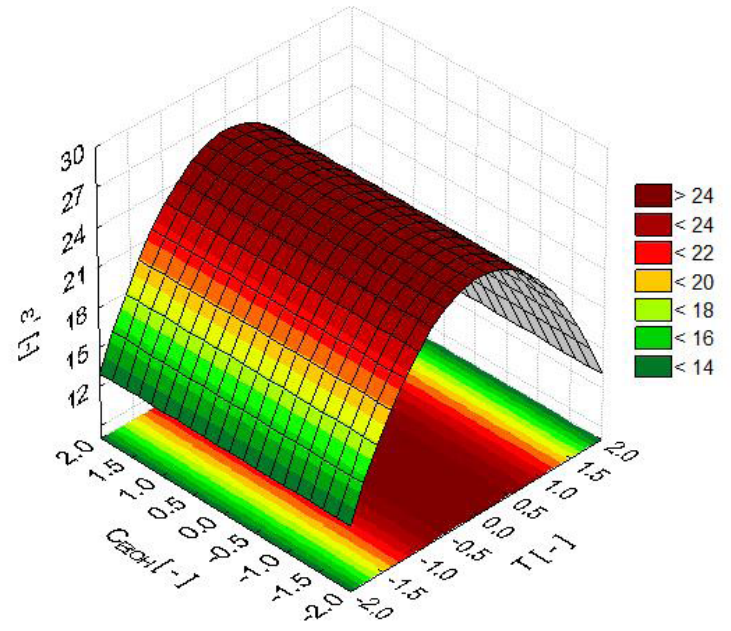

Figure 13. Response surface for $\mathrm{y}_{2}-\varepsilon^{\prime}[-]$ with fixed $\mathrm{C}_{\mathrm{NaCl}} x[-]$.

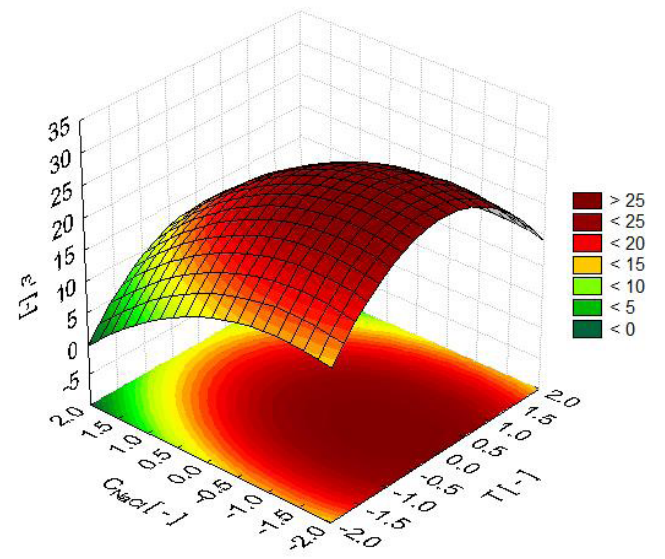

Figure 14. Response surface for $\mathrm{y}_{2}-\varepsilon^{\prime}[-]$ with fixed $\mathrm{C}_{\mathrm{EtOH}} \times[-]$.
Figure 15. Response surface for $y_{2}-\varepsilon^{\prime}[-]$ with fixed $T x[-]$.

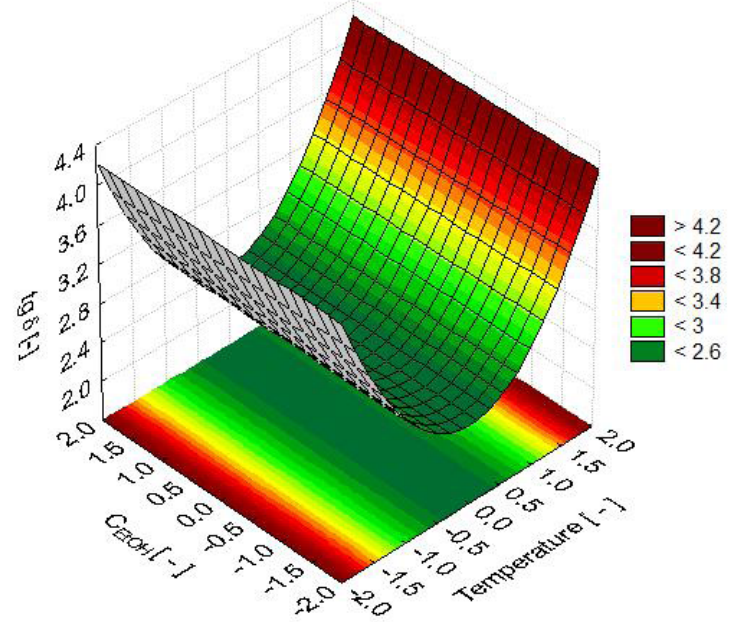

Figure 16. Response surface for $\mathrm{y}_{3}-\operatorname{tg} \delta[-]$ with fixed $\mathrm{C}_{\mathrm{NaCl}} \times[-]$.

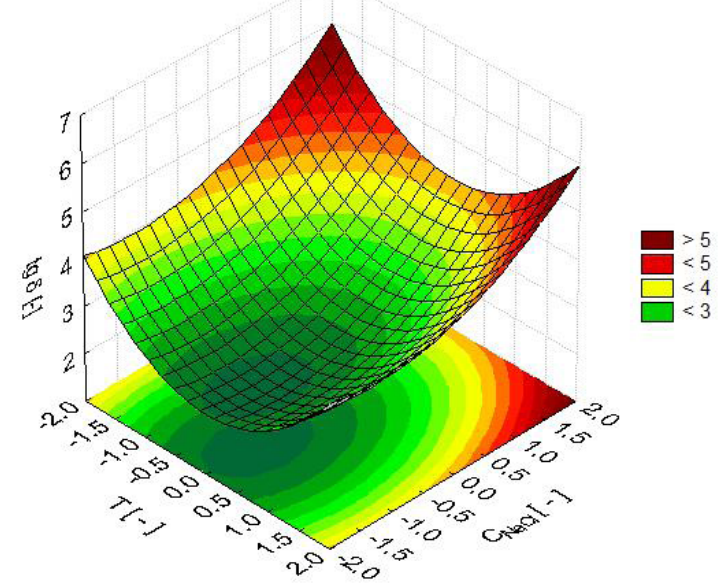

Figure 17. Response surface for $\mathrm{y}_{3}-\operatorname{tg} \delta[-]$ with fixed $\mathrm{C}_{\mathrm{EtOH}} \times[-]$. 


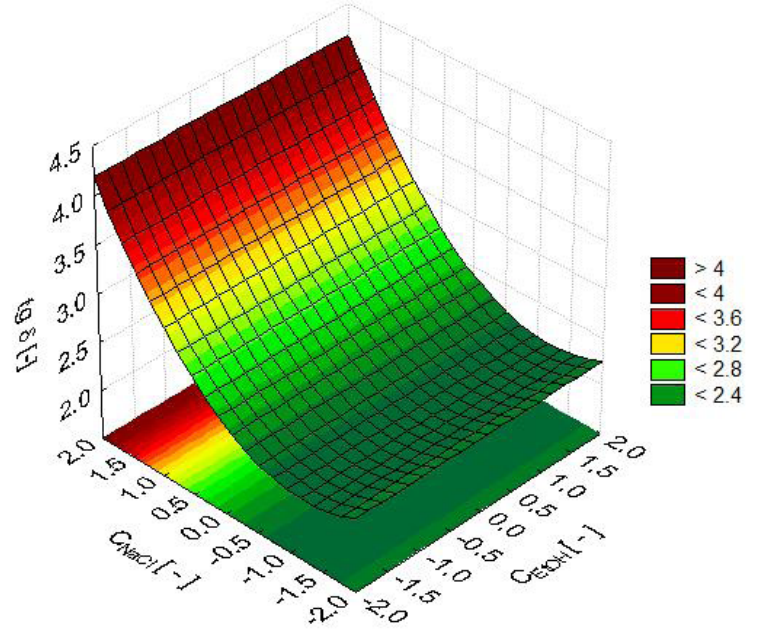

Figure 18. Response surface for $\mathrm{y}_{3}-\operatorname{tg} \delta[-]$ with fixed $\mathrm{T} X[-]$.

An evaluation of the surfaces shown above revealed that all the responses were influenced by the $\mathrm{NaCl}$ concentration $(x)$ and the temperature $(x)$. On analysing the concentration of $\mathrm{EtOH}(x)$, it can be seen that this variable did not influence $\varepsilon^{\prime}(y)$ or $\operatorname{tg} \delta(y)$, but for $\varepsilon^{\prime \prime}(y)$, the $\mathrm{EtOH}$ concentration was the variable that most influenced the response. These findings are consistent with the $p$ significance levels presented in Tables 4, 5 and 6.

The variables that most affected the $\varepsilon^{\prime}(y)$ and $\operatorname{tg} \delta(y)$ responses were the $\mathrm{NaCl}$ concentration $(x)$ in the linear form and the operating temperature $(x)$ in the quadratic form.

Considering the experimental range investigated, the optimum point for dielectric heating was determined by means of a canonical analysis of the model fitted by the $y$ function. The $y$ function is related to the other responses ( $y 1$ and $y 2$ ), because this variable represents the ability of the substance to convert electromagnetic energy into heat.

The Maple 9.5 software was used to determine the operating conditions that would maximize the $\mathrm{y}_{3}(\operatorname{tg} \delta)$ response, and an analysis of Equation 12 indicated their optimal values, i.e., $\mathrm{C}_{\mathrm{NaCl}}=2.21 \% ; \mathrm{C}_{\mathrm{EtOH}}=4.64 \%$ and $\mathrm{T}=87^{\circ} \mathrm{C}$.

\section{Conclusions}

The results of this study indicated that the variables that most strongly influenced the responses of dielectric constant $\left(\varepsilon^{\prime}\right)$ and dissipation factor $(\operatorname{tg} \delta)$ were the sodium chloride concentration, followed by the temperature of the blend. The variable that most influenced the response of dielectric loss factor $(\varepsilon ")$ was the ethanol concentration. The variable that exerted the least influence on the responses $\varepsilon$ ' and $\operatorname{tg} \delta$ was also found to be the ethanol concentration.

The dielectric properties of an ethanol solution undergo significant changes in response, for example, to variations in the $\mathrm{NaCl}$ concentration and in the temperature.
This indicates that such variations exert an influence during the microwave heating of these mixtures, a finding that is consistent with other studies published in the literature and cited in this paper.

In this study, we also found that, within the interval of ethanol concentrations investigated, the properties that define the ability of the material to convert electromagnetic energy into heat were not affected by microwave heating.

\section{References}

AHMED, J.; RAMASWAMY, H. S.; RAGHAVAN, V. G. S. Dielectric properties of butter in the MW frequency range as affected by salt and temperature. Journal of Food Engineering, v. 82, n. 3, p. 351-358, 2007. http://dx.doi.org/10.1016/j.jfoodeng.2007.02.049.

BICALHO, I. C.; MOGNON, J. L.; SHIMOYAMA, J.; ATAÍDE, C. H.; DUARTE, C. R. Separation of yeast from alcoholic fermentation in small hydrocyclones. Separation and Purification Technology, v. 87, p. 62-70, 2012. http://dx.doi.org/10.1016/j.seppur.2011.11.023.

BOOTY M.R., KRIEGSMANN G.A., Microwave heating and joining of ceramic cylinder: a mathematical model. Hampton: Institute for Computer Application in Science and Engineering, 1994. NASA contract 1948.

BRITO, A. Levedura "inteligente" acelera produção de álcool. Jornal Unicamp, Campinas, SP, 20 jul. 2003. p. 5. Available at: <http:// www.unicamp.br/unicamp/unicamp_hoje/jornalPDF/220pag05. pdf $>$. Accessed on: 8 june 2011.

CAMPAÑONE, L. A.; ZARITZKY, N. E. Mathematical analysis of microwave heating process. Journal of Food Engineering, v. 69 , n. 3, p. 359-369, 2005. http://dx.doi.org/10.1016/j. jfoodeng.2004.08.027.

CHA-UM, W.; RATTANADECHO, P.; PAKDEE, W. Experimental analysis of microwave heating of dielectric materials using a rectangular wave guide (MODE: TE10). Case study: water layer and saturated porous medium. Experimental Thermal and Fluid Science, v. 33, n. 3, p. 472-481, 2009. http://dx.doi.org/10.1016/j. expthermflusci.2008.11.008.

CHEN, Z.; ZHAO, K.-S. Dielectric relaxation spectroscopy of macroporous IER beads suspensions dispersed in primary alcohols and water-ethanol mixtures. Colloids and Surfaces A: Physicochemical and Engineering Aspects, v. 292, n. 1, p. 42-50, 2007. http://dx.doi.org/10.1016/j.colsurfa.2006.06.001.

DROUZAS, A. E.; SCHUBERT, H. Microwave application in vacuum drying of fruits. Journal of Food Engineering, v. 28, n. 2, p. 203-209, 1996. http://dx.doi.org/10.1016/0260-8774(95)00040-2.

EL BOULIFI, N.; ARACIL, J.; MARTíNEZ, M. Lipase-catalyzed synthesis of isosorbidemonoricinoleate: process optimization by response surface methodology. Bioresource Technology, v. 101, n. 22 , p. $8520-8525,2010$. http://dx.doi.org/10.1016/j. biortech.2010.06.094. PMid:20638275. 
Experimental design and response surface methodology applied to the dielectric properties of hydroalcoholic solutions containing sodium chloride

Morais, A. S. et al.

GADANI, D. H.; RANA, V. A.; BHATNAGAR, S. P.; PRAJAPATI, A. N.; VYAS, A. D. Effect of salinity on the dielectric properties of water. Indian Journal of Pure and Applied Physics, v. 50, p. 405-410, 2012.

GEEDIPALLI, S. S. R.; RAKESH, V.; DATTA, A. K. Modeling the heating uniformity contributed by a rotating turntable in microwave ovens. Journal of Food Engineering, v. 82, n. 3, p. 359-369, 2007. http://dx.doi.org/10.1016/j.jfoodeng.2007.02.050.

KINGSTON, H. M.; HASWELL, S. J. Microwave enhanced chemistry: fundamentals, sample preparation and applications. Washington: American Chemical Society, 1997. 4729 p.

KÖRBAHTI, B. K.; RAUF, M. A. Response surface methodology (RSM) analysis of photo induced de coloration of toludine blue. Chemical Engineering Journal, v. 136, n. 1, p. 25-30, 2008. http://dx.doi.org/10.1016/j.cej.2007.03.007.

KOSKINIEMI, C. B.; TRUONG, V. D.; MCFEETERS, R. F.; SIMUNOVIC, J. Effects of acid, salt and soaking time on the dielectric properties of acidified vegetables. International Journal of Food Properties, v. 16, n. 4, p. 917-927, 2013. http://dx.doi. org/10.1080/10942912.2011.567428.

KOSKINIEMI, C. B.; TRUONG, V.-D.; SIMUNOVIC, J.; MCFEETERS, R. F. Improvement of heating uniformity in packaged acidified vegetables pasteurized with a $915 \mathrm{MHz}$ continuous microwave system. Journal of Food Engineering, v. 105, n. 1, p. 149-160, 2011. http://dx.doi.org/10.1016/j.jfoodeng.2011.02.019.

MASKAN, M. Microwave/air and microwave finish drying of banana. Journal of Food Engineering, v. 44, n. 2, p. 71-78, 2000. http://dx.doi.org/10.1016/S0260-8774(99)00167-3.

MEREDITH, R. J. Engineer's handbook of industrial microwave heating. Exeter: The Institution of Electrical Engineers, 1998. 363 p. http://dx.doi.org/10.1049/PBPO025E.

METAXAS, A. C.; MEREDITH, R. J. Industrial microwave heating. London: Peter Peregrinus Ltd., 1993. 357 p.

MONTGOMERY, D. C. Design and analysis of experiments. 5th ed. New York: John Wiley \& Sons, 2001. 637 p.

OLIVEIRA, M. E. C.; FRANCA, A. S. Microwave heating of foodstuffs. Journal of Food Engineering, v. 53, n. 4, p. 347-359, 2002. http://dx.doi.org/10.1016/S0260-8774(01)00176-5.

PEYRE, F.; DATTA, A.; SEYLER, C. Influence of the dielectric property on microwave oven heating patterns: application to food materials. The Journal of Microwave Power and Electromagnetic Energy, v. 32, n. 1, p. 3-15, 1997. http://dx.doi.org/10.1080/08 327823.1997.11688318. PMid:9177015.

PROSETYA, H.; DATTA, A. Batch microwave heating of liquids: an experimental study. The Journal of Microwave Power and Electromagnetic Energy, v. 26, n. 4, p. 215-226, 1991. http:// dx.doi.org/10.1080/08327823.1991.11688160.

PULIGUNDLA, P.; ABDULLAH, S. A.; CHOI, W.; JUN, S.; OH, S.-E.; KO, S. Potentials of microwave heating technology for select food processing applications: a brief overview and update. Journal of Food Processing \& Technology, v. 4, n. 11, p. 278, 2013. http://dx.doi.org/10.4172/2157-7110.1000278.

RAVIKUMAR, K.; PAKSHIRAJAN, K.; SWAMINATHAN, T.; BALU, $K$. Optimization of batch process parameters using response surface methodology for dye removal by a novel adsorbent. Chemical Engineering Journal, v. 105, n. 3, p. 131-138, 2005. http://dx.doi.org/10.1016/j.cej.2004.10.008.

SUN, T.; TANG, J.; POWERS, J. R. Antioxidant activity and quality of asparagus as affected by microwave-circulated water combination and conventional sterilization. Journal of Food Chemistry, v. 100, n. 2, p. 813-819, 2007. http://dx.doi. org/10.1016/j.foodchem.2005.10.047.

TANAKA, F.; UCHINO, T.; HAMANAKA, D.; ATUNGULU, G. G.; HUNG, Y.-C. Dielectric properties of mirin in the microwave frequency range. Journal of Food Engineering, v. 89, n. 4, p. 435-440, 2008. http://dx.doi.org/10.1016/j.jfoodeng.2008.05.029.

YIN, C. Microwave-assisted pyrolysis of biomass for liquid biofuels production. Bioresource Technology, v. 120, p. 273-284, 2012. http://dx.doi.org/10.1016/j.biortech.2012.06.016. PMid:22771019.

ZHANG, M.; TANG, J.; MUJUMDAR, A. S.; WANG, S. Trends in microwave-related drying of fruits and vegetables. Trends in Food Science \& Technology, v. 17, n. 10, p. 524-534, 2006. http://dx.doi.org/10.1016/j.tifs.2006.04.011.

ZHU, J.; KUZNETSOV, A. V.; SANDEEP, K. P. Mathematical modeling of continuous flow microwave heating of liquids: effects of dielectric properties and design parameters. International Journal of Thermal Sciences, v. 46, n. 4, p. 328-341, 2007. http://dx.doi.org/10.1016/j.ijthermalsci.2006.06.005. 